\title{
Investments, Credit, and Corporate Financial Distress: Evidence from Central and Eastern Europe
}

\author{
Kadri Männasoo, Peeter Maripuu, and Aaro Hazak \\ Department of Economics and Finance, Tallinn University of Technology, Tallinn, Estonia, \\ kadri.mannasoo@ttu.ee
}

\begin{abstract}
Although they are instrumental for economic development, productivity-enhancing corporate investments may increase the financial vulnerability of companies, especially in an economic and financial crisis. We employ an instrumental probit model with the aim of finding evidence for the investment and credit patterns that led companies into financial distress during the global financial crisis 2009-2010. The company-level micro-data for our study on three Central and East European countries-Hungary, Bulgaria, Romania and two Baltic countries, Latvia and Lithuania-originates from two independent surveys, the Business Environment and Enterprise Performance Survey conducted in 2008 and the Financial Crisis Survey conducted in 2009/2010. Both were carried out jointly by the EBRD and the World Bank. Our results emphasize a substantial adverse impact from investment intensity and debt financing on company financial soundness during a crisis. On top of that, we discover a strong non-linear pattern in the sensitivity of company distress to its investmentfinancing nexus.
\end{abstract}

KEYWORDS: Central and Eastern Europe, corporate financial distress, credit, economic crisis, investments

\section{Introduction and Background}

Corporate investments are instrumental for productivity improvement and industry competitiveness. Syverson (2011) documents robust empirical evidence on positive correlation between higher productivity and corporate survival across countries, timeperiods, and industries. At the company level however, investments present not only opportunities but also significant risks. Debt repayments on investments funded with external financing put a pressure on the company's cash flows, but there might be a considerable time-lag before productivity gains from the investments emerge, and in the worst case the investments may have a negative return. Furthermore, investments tend to increase the operational costs of installing, operating, and maintaining new technology or production equipment. Although investment is overall expected to increase the productivity, competitiveness, and profitability of a company, it may cause its financial position to suffer, especially during the setup phase.

However, the financial vulnerability of a company not only depends on its investment and credit decision but is also strongly intertwined with the broader economic and financial environment. The macroeconomic climate tends to have a strong influence on companies' investment and credit decision ex ante, and it plays a critical role in the success 
and profitability of the investments ex post. While excessive risk aversion toward investment hinders company competitiveness and growth from enjoying positive scale effects, and overly optimistic stance may lead to overinvestment and low or even negative returns. Both of these are undesirable market frictions that might be alleviated with appropriate policy measures. Our study seeks to find evidence for what the impact of investment and the credit profiles of companies were and on whether they became financially distressed in the trough of the financial recession in 2009-2010.

Determinants of corporate financial distress have received extensive coverage in the literature. For comprehensive surveys, see for example, Balcaen and Ooghe (2006), Aziz and Dar (2006), Bellovary, Giacomino, and Akers (2007), and Altman et al. (2014). As expected, many researchers have demonstrated that macroeconomic downturns tend to increase the risk of company failures. Richardson, Kane, and Lobingier (1998) base their theoretical argument on Beaver's (1966) model, which stresses the importance of a liquidity buffer for company survival, and they argued that weaker demand induced by a recession reduces companies' internal cash flows, and a possible credit crunch hampers the access of creditconstrained companies to external cash flows, thus increasing the risk of financial distress. Bhattacharjee et al. (2009) have formulated a competing exit risks model, in which one outcome is that company exits are low in stable macroeconomic environment and high during a recession because the total pool of investors and available investment financing is contracting at that time.

Another stylized fact is that company size and age play an important role in whether a company becomes distressed. Several studies have reported empirical evidence that small companies are more prone to risk of financial distress (see e.g. Bickerdyke, Lattimore, and Madge 2000; Ohlson 1980; Tsai 2013). Dunne and Hughes (1994) explain that this is because the scale effect is insufficient. Thornhill and Amit (2003), building on a resource-based view of operating a company, argue that young companies are at risk because they lack valuable resources and capabilities, while older companies may fail because they are unable to adapt to a changing competitive environment. Moreover, Hazak and Männasoo (2010) find that the risk of default appears as a U-shaped function of the time the company has survived, meaning that financial vulnerability tends to decrease as a company establishes itself in the market, but returns upward as the company ages as exposure to internal problems and external shocks accumulates.

Although several authors have included investment-related variables in their financial distress models, empirical evidence about the effect of higher capital investment volumes on company financial distress remains mixed. Some studies report a strong positive relationship (e.g. Aziz, Emanuel, and Lawson 1988; Aziz and Lawson 1989; Gentry, Newbold, and Whitford 1985a) while others have found no support for that (Gentry, Newbold, and Whitford 1985b; McKee and Lensberg 2002; Min and Lee 2005 among others). Long-term capital investment appears to improve company's performance when there is a positive economic outlook, while investments increase risks at the onset of a downturn (Männasoo and Maripuu 2015). Kane and Richardson (2002) have found companies that are already distressed to have a better chance of recovery if they contract their extant asset base, while Flagg, Kudrimoti, and Margetis (2011) see a reduction in 
capital expenditure together with an increase in R\&D spending as a way out of distress.

The literature on the determinants of the financing of investments has emphasized the crucial role played by the extant structure of cash flows and credit constraints-see Harris and Raviv (1991), Shleifer and Vishny (1997) and Hubbard (1998), or more recently Mohamed, Amel, and Bouri (2013) for excellent literature surveys.

Theoretical arguments by Aghion et al. (2010, 2012) suggest that countercyclical R\&D and other productivity enhancing investments are justified unless the company is credit constrained. In their theoretical model, a company facing an internal cash flow shock becomes more credit constrained because its ability to provide collateral worsens along with the internal cash flows, and this in turn reduces its ability to invest. Barlevy (2007), in contrast, argues that the procyclical nature of $R \& D$ investments stems from a dynamic externality inherent to $R \& D$, making entrepreneurs short-sighted so that they concentrate their innovation in boom times.

Campello et al. (2011) looked into the interaction between the investment decisions of companies and their internal and external liquidity in the 2009 crisis, finding that creditconstrained companies appeared to substitute internal liquidity with external credit lines in order to make investments during the crisis.

Popov (2014) documents the negative effect of credit constraints on human capital investments and shows that this effect is stronger in education-intensive industries and in industries facing good global growth opportunities. Avarmaa, Hazak, and Männasoo (2013) demonstrate the effects that financial leverage and credit constraints have on labour productivity. Tian and Wang (2014) moved forward and showed that lower credit constraints in the form of failuretolerant investors lead to higher ex post innovation productivity in venture capital backed startup companies and more so for ventures born during recessions.

The adverse effect of credit constraints on capital investments (see e.g. Fazzari, Hubbard, and Petersen 1988; Li 2011) has found strong empirical support. Moreover, credit constraints particularly appear to restrain investments in small and young companies (see e.g. Hadlock and Pierce 2010; Saeed and Vincent 2012) and in domestic companies, more so than in foreign ones (Gorodnichenko and Schnitzer 2013). Schoder (2013) adds to the discussion on the cyclical sensitivity of investments by stressing the importance of patterns of supply (i.e. cost of finance and access to it) and demand (i.e. investment opportunities) conditions. He shows that investment has been driven by the demand side rather than the supply side of capital markets during the most severe recession.

In the Central and Eastern European countries (CEE) context, Nivorozhkin (2005) has shown that leverage is significantly associated with country and industry effects, and is positively related to the share of private credit to GDP. Črnigoj and Verbič (2014) showed that corporate investments in Slovenia were significantly affected by financial constraints during the global financial crisis. Avarmaa, Hazak, and Männasoo (2011) find that size has a positive effect and age a negative one on the leverage of Baltic companies and that multinational companies tend to be less credit constrained in economic downturns. Beyond the broad-based evidence that liquidity, leverage, and profitability ratios form a robust set of firm distress predictors Maripuu and Männasoo (2014), based on Estonian companies data, show that companies distress risk varies in economic cycle and 
investment intensity. Our study contributes to the literature by investigating how the combination of investment intensity and debt financing affects a company's distress in an adverse economic environment. In doing so, the key methodological challenge is to address the non-linearity and endogeneity issues that arise from a limited dependent variable and explanatory variables likely to be correlated with the error term.

Gorodnichenko and Schnitzer (2013) tackled the endogeneity problem in their study on determinants of innovation activity using instrumental variable estimators. Schoder (2013) and Männasoo and Maripuu (2015) use the General Method of Moments (GMM) estimator, which allows them to obtain consistent parameter estimates. We apply instrumental variable estimators to identify the effects of investment intensity and external debt upon company distress using two independently conducted surveys where the same companies were questioned both before and after the start of the financial crisis in 2009 /2010. Beyond that, we employ both linear (2-Step-Least-Squares and Limited Information Maximum Likelihood methods and GMM) and non-linear (2-step Probit and Maximum Likelihood Probit) instrumental variable methods.

The article is organized as follows. The introductory section is followed by the descriptions of the data and the research methodology is discussed in second section. Then, the results are reported and discussed in third section and conclusion is provided in fourth section.

\section{Data and Methodology}

The company-level data for our study originate from two surveys - the fourth wave of the Business Environment and Enterprise Performance Survey (BEEPS) and all three waves of the Financial Crisis Survey (FCS), both conducted jointly by the European Bank for Reconstruction and Development (EBRD) and the World Bank Group (World Bank) in 2008/2009 and 2009/2010, respectively. In addition, we have used macroeconomic statistics from Eurostat and EBRD.

The BEEPS was conducted in five waves in 1999-2014 and it covers 30 transition countries. The FCS was conducted in three waves over 2009-2010 on a sub-selection of the companies that had been interviewed for the fourth wave of the BEEPS, and it covers six countries. For our study, we have excluded Turkey and used data for five EU member countries Bulgaria, Latvia, Lithuania, Hungary, and Romania as a more homogeneous sample. We can argue (see e.g. Gorodnichenko and Schnitzer 2013) that these were the European countries hit hardest by the recent financial crisis. Figures from Eurostat show the average decline in GDP in 2009 in these six countries was higher than the average of $4.5 \%$ for the European Union of 28 countries, as GDP declined by $5.5 \%$ in Bulgaria, $6.8 \%$ in Hungary, $17.7 \%$ in Latvia, $14.8 \%$ in Lithuania, and $6.6 \%$ in Romania. We chose these specific waves of the surveys so that we could focus on two distinct episodes - the height of the economic upswing in 2007 and the effect of the financial crisis in 2009/2010. Figure 1 shows that the first negative effect of the global financial crisis on gross value added was seen in late 2008 and early 2009, while there were significant variances in the depth of the crisis between the countries, and the bottom was reached at different times. 
Private sector credit to GDP was following a path of growth at the end of 2008, and no visible deleveraging happened before 2010.

Our dataset covers companies from 18 sub-industries (NACE 2), of which 11 are manufacturing sub-industries and three are in wholesale and retail trade, while the others are transportation and storage, construction, hotels, and restaurants, and information technology. The sample structure of the BEEPS and the FCS was designed to be representative of the population of companies in each country using stratified random sampling. These surveys did not include companies with fewer than two or more than 10,000 employees, nor companies with 100\% government ownership and companies from highly regulated sectors, such as financial activities, utilities, mining, and rail transport. We have additionally excluded all firms with $50 \%$ or higher government or state ownership and firms with payments overdue by more than 90 days according to the precrisis BEEPs survey.

Both the BEEPS and the FCS comprise self-reported measures of companies' investments, credit constraints and financial distress. For a short description of the variables used for our study, together with the source of data and descriptive statistics, see Table 1. From the estimation sample of 1106 companies, 62\% had made an investment in PPE during 2007 and $29 \%$ had used either bank credit or trade credit to finance their investments. The descriptive statistics broken down by company's distress status and by countries are to be found from online Supplementary Material S2, available online (see Table S5).

Moreover, the kernel density estimations, see Figure 2, reveal that those companies which had not financed investments with external credit before the economic crisis nor made any investments were less subject to financial distress, especially the non-investing companies. The solid line representing distressed companies shows the higher probability mass at higher levels of debt financing (LTC), as well as at higher levels of investment intensity (ITS $\mathrm{PPE})$.

Next, we look closer into the financing structure of investments into property, plant, and equipment (PPE), outlining equity financing (share capital and retained earnings), bank debt, trade credit (payables to suppliers and advances from customers), and other sources of financing (e.g. non-bank-debt). The financing structure in Figure 3 is shown separately for distressed and non-distressed firms (non-weighted mean) for total sample (left graph) and by countries (right graph). The sample overall structure implies a higher internal funding share $(68 \%)$ for the group of non-distressed companies relative to the group of distressed companies $(54 \%)$, whereas the bank financing had an opposite pattern with $24 \%$ for non-distressed and $36 \%$ for distressed companies. Trade credits had an about equivalent share of $5 \%$ in both company groups. The distressed companies had also higher share of "other financing," but the overall share of this source of funding remained low in both groups (3\% for non-distressed and $5 \%$ for distressed group). The sample overall financing structure is coherent in all five countries, with distressed companies being more exposed to external financing compared with non-distressed firms. 
Table 1. Description of variables and summary statistics.

\begin{tabular}{|c|c|c|c|c|c|c|c|}
\hline Name & Description [Unit] & Source & Mean & Std.Dev & Min & Max & $\mathbf{N}$ \\
\hline \multicolumn{8}{|l|}{$\begin{array}{l}\text { Outcome } \\
\text { variable }\end{array}$} \\
\hline $\begin{array}{l}\text { Company } \\
\text { Distress }\end{array}$ & $\begin{array}{l}\text { 1, if company has filed for } \\
\text { insolvency (or bankruptcy), or } \\
\text { at least two out of the three } \\
\text { follow- ing events have } \\
\text { occurred in the last } 12 \text { months: } \\
\text { (1) overdue to financial } \\
\text { institutions, (2) } 90 \text { days over- } \\
\text { due to trade creditors, (3) } \\
\text { restructuring of any out- } \\
\text { standing liabilities; } 0 \text { otherwise } \\
{[0 ; 1]}\end{array}$ & FCS & 0.233 & $(0.423)$ & 0 & 1.000 & 1106 \\
\hline \multicolumn{8}{|l|}{$\begin{array}{l}\text { Endogenous, } \\
\text { instrumented } \\
\text { variables }\end{array}$} \\
\hline ITSPPE & $\begin{array}{l}\text { Ratio of annual total } \\
\text { Investments to Property, Plant } \\
\text { and Equipment (PPE) to sales } \\
\text { [\%] } \\
\text { Ratio of annual total }\end{array}$ & BEEPs & 6.736 & (18.176) & 0 & 341.426 & 1106 \\
\hline ITSPE & $\begin{array}{l}\text { Investments to Plant and } \\
\text { Equipment (PE) to sales [\%] } \\
\text { Percentage of PPE investments }\end{array}$ & BEEPs & 5.429 & (13.666) & 0 & 173.958 & 1093 \\
\hline LTC & $\begin{array}{l}\text { financed by bank loans and } \\
\text { suppliers credits [\%] }\end{array}$ & BEEPs & 19.599 & $(34.027)$ & 0 & 100.000 & 1106 \\
\hline \multicolumn{8}{|l|}{$\begin{array}{l}\text { Exogenous } \\
\text { variables }\end{array}$} \\
\hline Size & $\begin{array}{l}1 \text { if the company has more than } \\
50 \text { employees }[0 ; 1] \\
\text { Age in years since the company } \\
\text { started operations in the }\end{array}$ & BEEPs & 0.393 & $(0.489)$ & 0 & 1.000 & 1106 \\
\hline Age & $\begin{array}{l}\text { particular country. } \\
\text { transition countries the } \\
\text { beginning year is set to } 1987 \text { if } \\
\text { reported earlier [years] }\end{array}$ & BEEPs & 13.35 & $(5.010)$ & 1 & 23.000 & 1106 \\
\hline SectorVA, 2009 & $\begin{array}{l}\text { Percentage change in } \\
\text { subindustry value added in } \\
2009[\%]\end{array}$ & Eurostat & -14.535 & (15.489) & -67.2 & 80.100 & 1106 \\
\hline \multicolumn{8}{|c|}{$\begin{array}{l}\text { Instruments for } \\
\text { Endogenous } \\
\text { variables* }\end{array}$} \\
\hline UniGrade & $\begin{array}{l}\text { Percentage of the company } \\
\text { workforce having a uni- versity } \\
\text { degree or higher in } 2007 \text { [\%] }\end{array}$ & BEEPs & 17.953 & (23.335) & 0 & 100.000 & 1106 \\
\hline CrGDP & $\begin{array}{l}\text { Share of private credit to GDP } \\
\text { in } 2007 \text { [\%] }\end{array}$ & EBRD & 50.066 & $(15.277)$ & 34.7 & 81.000 & 1106 \\
\hline
\end{tabular}

* Instruments include additionally country and sector dummies. 

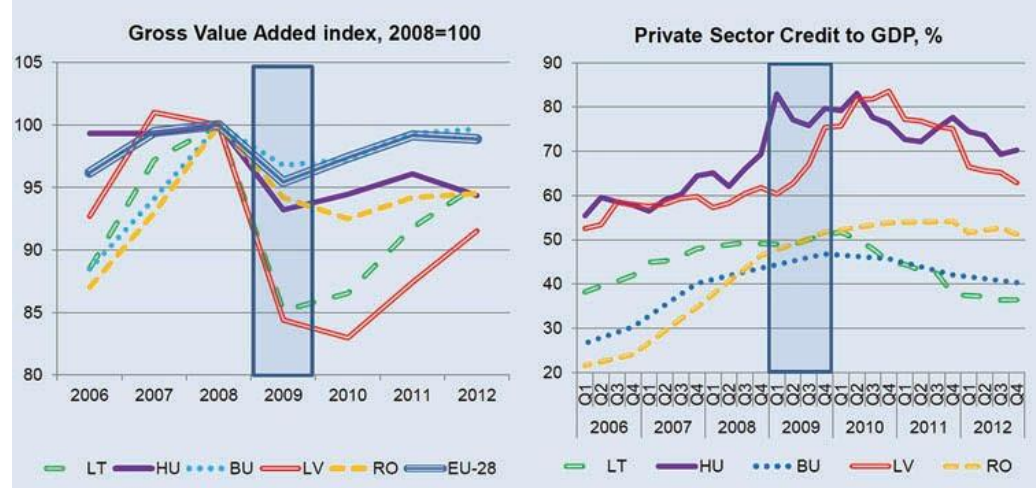

Figure 1. Gross value added by all NACE categories and private sector credit to GDP, 2006-2012. Source: The European Central Bank; Eurostat.Note: BEEPS and FCS fieldwork dates highlighted.
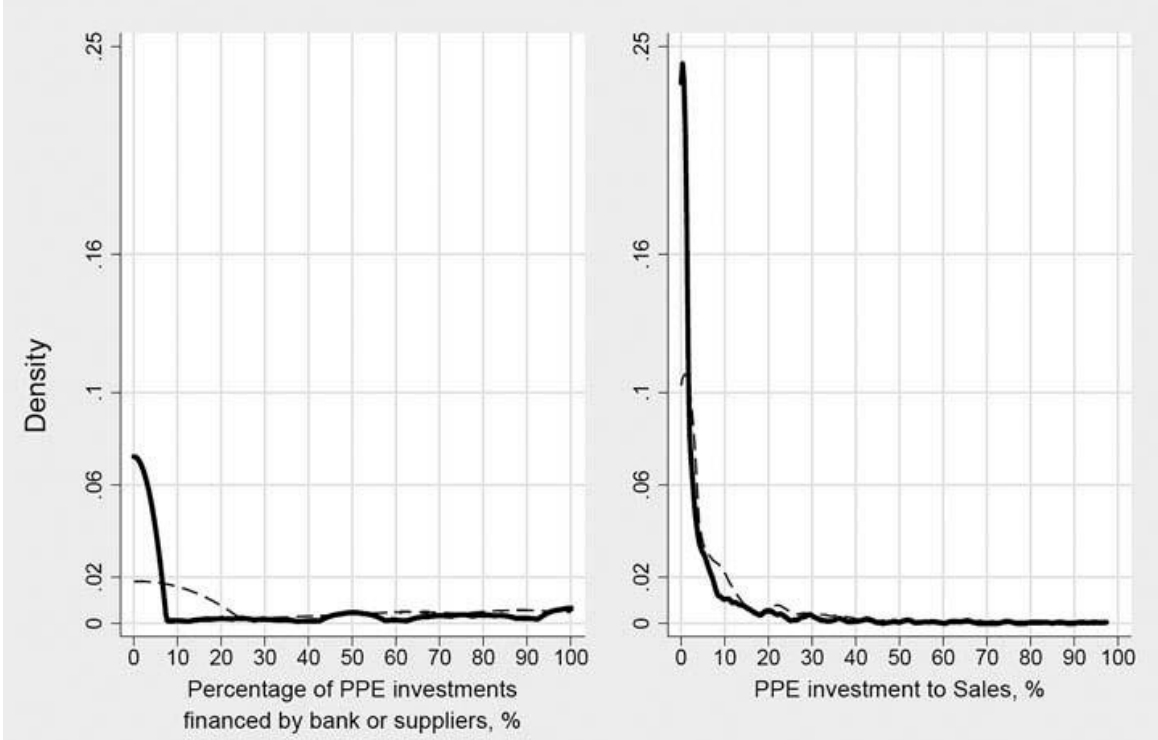

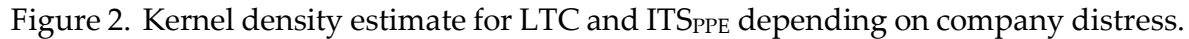
Source: Authors' calculation on the BEEPs data.
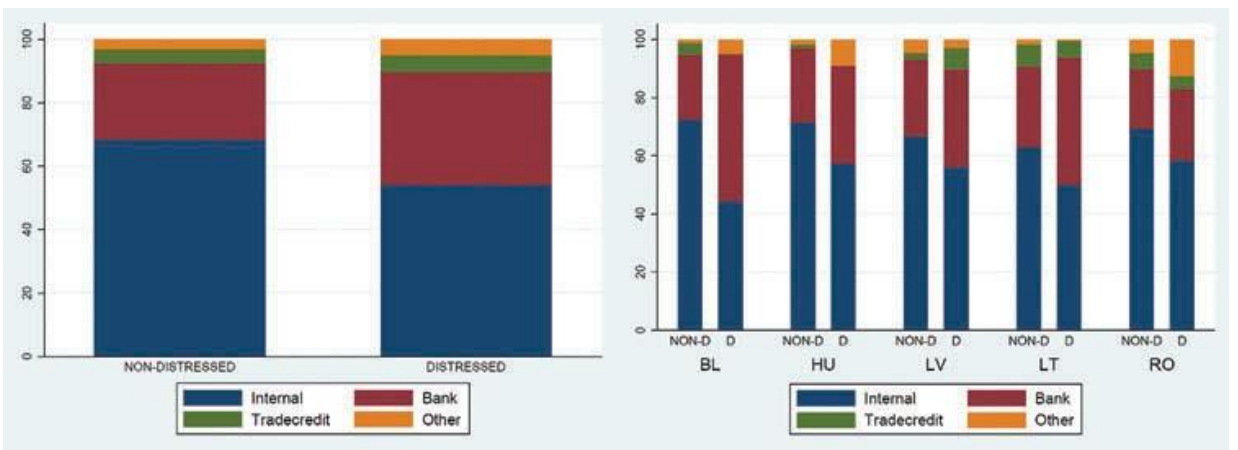

Figure 3. Proportion of company's total purchase of fixed assets financed by different sources, $\%$. Source: Authors' calculations on the BEEPs data. 
The effects of investment intensity and gearing on distress probability are estimated with an instrumental variable probit model. Like Gorodnichenko and Schnitzer (2013), we have chosen to use the instrumental variables method instead of simple linear (Ordinary Least Squares) or non-linear estimators (probit or logit) to avoid inconsistent parameters caused by highly endogenous relationships between investments intensity, investments leverage, and distress probability. The endogeneity mainly stems from ex ante stronger (weaker) companies investing and borrowing more (less) ex post.

To define our dependent variable of company distress, we use the FCS data only, whereas all company-level explanatory variables were retrieved from the pre-crisis BEEPS dataset. Additionally, we exclude companies, which reported overdue payments of taxes and utility costs before the crisis in the BEEPS survey, in order to exclude the effect of those companies that were already in trouble before the crisis and might hence distort the predetermined nature of our explanatory variables.

$$
\begin{aligned}
\text { Distress }_{i s c, t}= & 2009 / 2010 \\
= & \Phi\left(\beta_{0}+\alpha_{0} I_{T S} S_{i s c, t=2007}+\alpha_{1} L_{T C} C_{i s c, t=2007}+\beta_{1} \text { Age }_{i s c, t=2007}+\beta_{2} \text { Size }_{i s c, t=2007}\right. \\
& \left.+\beta_{3} \text { SectorVA }_{i s c, t=2009}+\varepsilon_{i s c, t}\right)
\end{aligned}
$$

Our baseline estimator is the instrumental variable probit (IV Probit) model, where $\Phi$ denotes the cumulative standard normal probability distribution function. The parameters $\alpha_{0}$ and $\alpha_{1}$ denote our key explanatory, but endogenous variables, investment to sales (ITS) and loan-to-cost (LTC), both of which have been instrumented with country and sector dummies, the country credit-to-GDP ratio in 2007, and the 2007 share of employees holding a university degree. The country and sector effects and the proportion of employees with a university degree are significantly associated with investment intensity and external debt funding of investments in reduced-form equation constituting relevant instruments. The relevance of our instruments is in-line with Nivorozhkin (2005) and Popov (2014) who stress the macroeconomic and human capital influences on capital structure and financing choices. The instruments are uncorrelated with the outcome variable or company distress probability and thus excluded from the structural equation. The validity of instruments is confirmed by over- identification tests, see result diagnostics in Table 2 . The subscripts $i=1 \ldots 1106, s=1 \ldots 6, c=1 \ldots .5$ and $t=2007$, 2009/2010 denote firms, industries, countries, and years, respectively.

We present our baseline non-linear instrumental variable full maximum likelihood probit estimates and two-step probit estimates along with the linear (2SLS, LIML, and GMM) estimates in Table 2 to enable some comparison and allow robustness checks across the results. The stronger outcome of the non-linear IV Probit model explicates the importance of considering the non-linearity of the dependent variable or the distress variable with respect to the covariates. The marginal effects of IV Probit at varying levels of investment and external debt financing of investments are outlined in Figure 4 and Figure 5. The overidentification tests are provided along with the model estimates, and these confirm the validity of our instruments. A number of robustness checks are conducted to validate our baseline results and these are available as the Supplementary Material online. 
Table 2. Default equations with IV estimators.

\begin{tabular}{lccccc}
\hline Name & IV Probit 2-Step & IV Probit FIML & 2SLS & LIML & GMM \\
\hline ITSPPE & $0.044 * *$ & $0.032 * * *$ & 0.012 & 0.014 & $0.012 *$ \\
& $(0.022)$ & $(0.017)$ & $(0.007)$ & $(0.009)$ & $(0.007)$ \\
LTC & $0.026 * * *$ & $0.016 * * *$ & $0.008 * * *$ & $0.008 * *$ & $0.008 * * *$ \\
& $(0.008)$ & $(0.008)$ & $(0.003)$ & $(0.003)$ & $(0.003)$ \\
Age & -0.014 & -0.009 & -0.004 & -0.004 & -0.004 \\
& $(0.011)$ & $(0.007)$ & $(0.003)$ & $(0.003)$ & $(0.003)$ \\
Size & $-0.395 * * *$ & $-0.244 * * *$ & $-0.121 * * *$ & $-0.123 * * *$ & $-0.118 * * *$ \\
& $(0.138)$ & $(0.103)$ & $(0.039)$ & $(0.042)$ & $(0.038)$ \\
Crisis, 2009 & 0.002 & 0.001 & 0.001 & 0.001 & 0.001 \\
& $(0.004)$ & $(0.002)$ & $(0.001)$ & $(0.001)$ & $(0.001)$ \\
Intercept & $-1.187 * * *$ & $-0.754 * * *$ & $0.108 * *$ & $0.095 *$ & $0.109 * *$ \\
& $(0.206)$ & $(0.126)$ & $(0.055)$ & $(0.058)$ & $(0.055)$ \\
N & 1106 & 1106 & 1106 & 1106 & 1106 \\
Log-Likelihood & & -10708 & & & \\
chi-square & 34.397 & 142.243 & 42.399 & 39.446 & 43.088 \\
P & 0 & 0 & 0 & 0 & 0 \\
Over-identification test & 4.410 & & 4.436 & 4.261 & 4.436 \\
Over-identification & 0.621 & & 0.618 & 0.641 & 0.618
\end{tabular}

Source: Authors' calculations. Dependent variable is company default from FCS survey data. The cycle gap variable is from Eurostat, the other explanatory variables refer to 2007 data from BEEPS.

Note: Hansen J-statistics used as overidentification test for 2SLS and GMM, Anderson-Rubin chi-square test used for LIML and Amemiya-Lee-Newey minimum chi-square statistics for IV-Probit.

Heteroskedasticity robust standard errors in parenthesis, based on inverse of the outer product matrix (Hessian) or information matrix in sandwich form. ${ }^{* * *}, * *,{ }^{*}$ stand for $1 \%, 5 \%$ and $10 \%$ level statistical significance respectively.

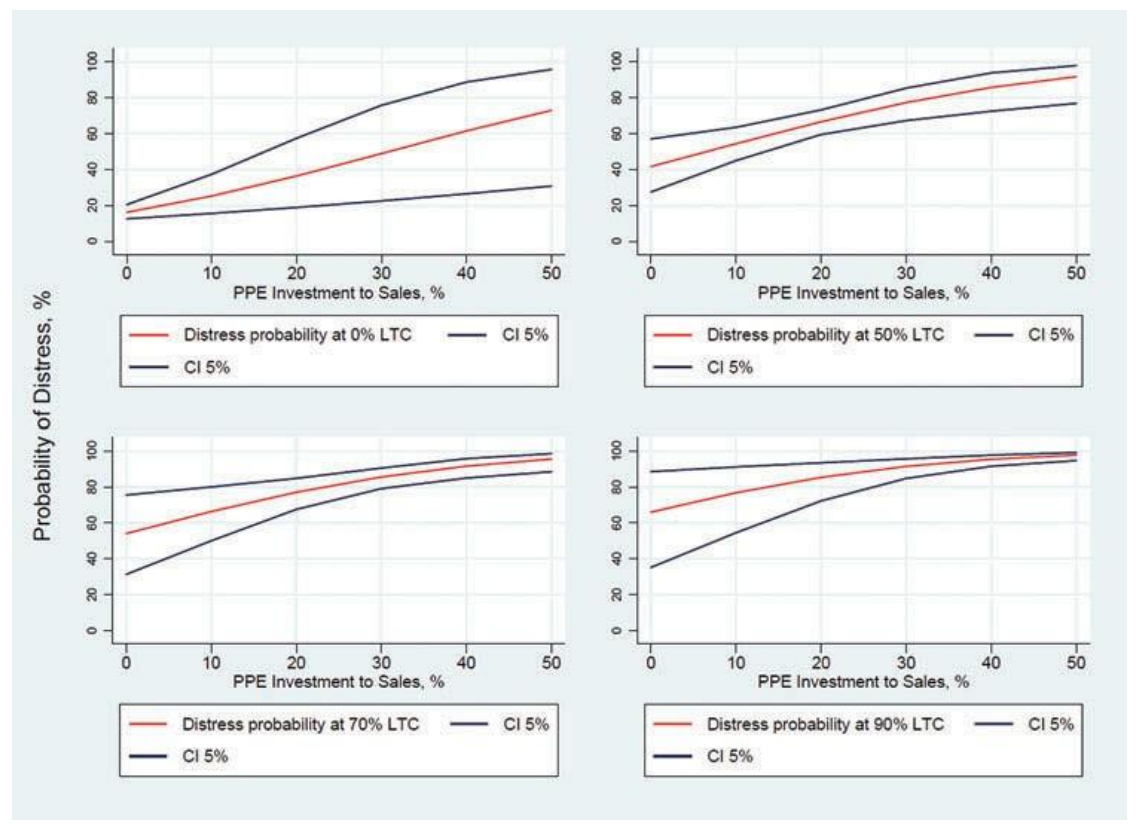

Figure 4. Distress probability at different levels of LTC.

Source: Authors' calculations based on IV Probit maximum likelihood estimates on the BEEPs and theFCS data. 

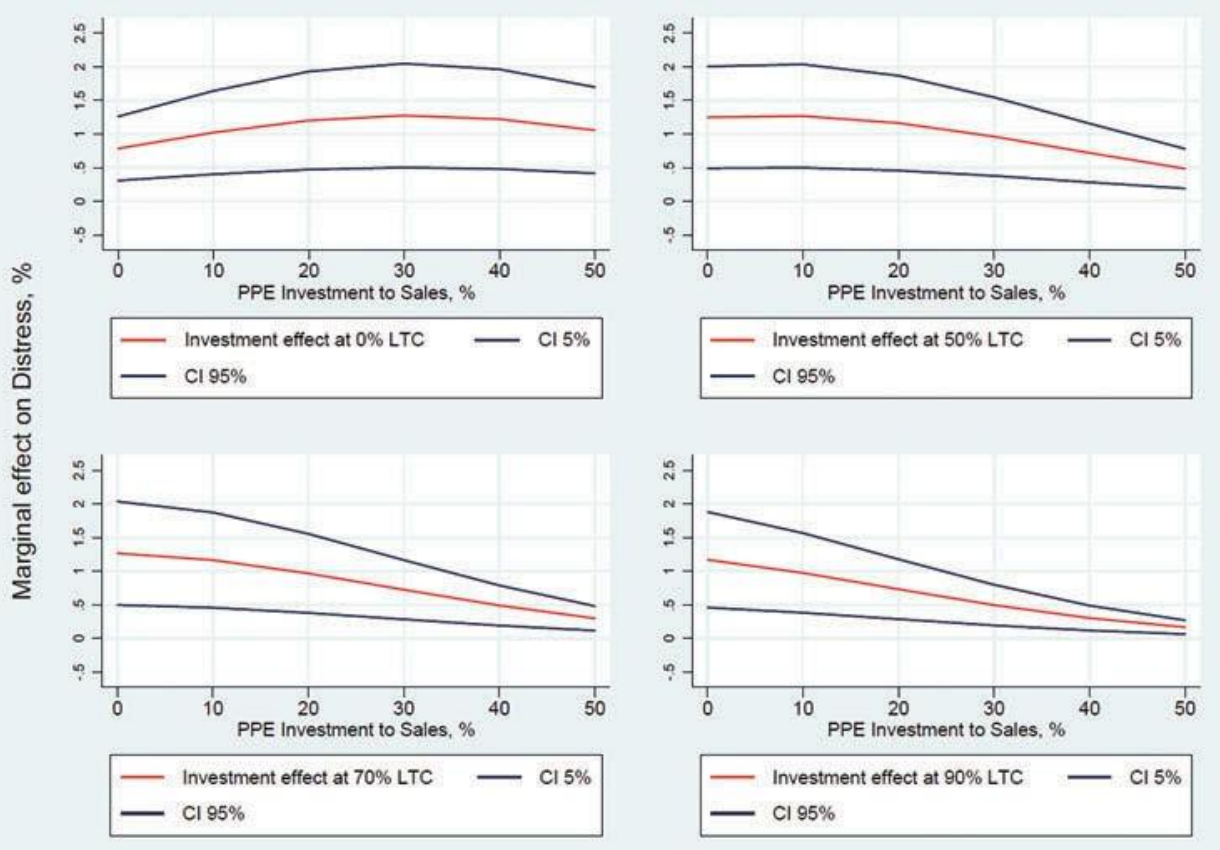

Figure 5. Marginal effects on distress for different levels of LTC.

Source: Authors' calculations based on IV Probitmaximum likelihood estimates on the BEEPs and theFCS data.

\section{Results}

We find that both higher pre-crisis investment intensity and higher debt financing of investments increase the probability of a company facing distress in the aftermath of the crisis. The linear estimators (2SLS and GMM) show that a $10 \%$ increase in investment intensity, measured by the investments to sales ratio, results in an increase of $12-14 \%$ in the probability of the company being financially distressed (see Table 2). A $10 \%$ increase in the share of bank loans in the financing of new investments increases the probability of company distress by $8 \%$. Compared with those of previous studies, our results are in-line with the findings of Kane and Richardson (2002), who documented how reducing capital expenditures has a positive effect on a company's ability to recover from financial distress, and those of Männasoo and Maripuu (2015), who showed that expansion of investment in the wake of a downturn is detrimental for a company's financial strength. We explore the related issues in a country comparative context under the adverse economic conditions during the global financial crisis during 2009-2010.

The strongest determinant of company viability is its size, as companies with more than 50 employees are $12 \%$ less likely to encounter financial distress in our pooled sample. Although company size has been widely reported in the previous literature as an important determinant of survival (see e.g. Ohlson 1980; Tsai 2013), we show that company size plays a varying role at different stages of crisis being more significant in buffering the firm against crisis at the beginning of downturn, while becoming less 
important factor of resilience (if not a trigger of crisis) in longer term. Company age to the contrary becomes a significant remedy to crisis only in the later stages of downturn. The advantage of established firms in coping with the crisis might stem from stronger managerial experience and more deep-rooted relationships with their suppliers and customers. To control for possible U-shape relationship, in-line with Hazak and Männasoo (2010), we added squared effect of age into the model, but this step did not change our baseline results.

Investment gearing was a more detrimental factor at the beginning of the crisis, whereas the investment intensity became a significant cause of distress only after a prolonged period of adverse economic environment (see Table 3). The pattern of how firms reflected on crisis shows that at the early stages of crisis the first to become distressed are the small companies with high investment gearing. As the crisis evolves the size of the company becomes irrelevant if not a further trigger of distress for the companies with high pre-crisis investment intensity. The underutilized tangible and human capacities become a financial burden for the companies in a low-demand environment of the crisis.

The non-linearity of the instrumental probit model (IV probit) turns the coefficients interpretation into a non-trivial task. Therefore, the main results of the article are depicted on graphs Figure 4 and Figure 5, which illustrate the probability of distress at different investment and debt levels, and marginal effects at varying investment and debt levels, respectively. Companies, which use equity financing for new investments, exhibit an almost linear positive relationship between investment intensity and distress (see upper left panel of Figure 4). For those companies that use debt to finance new investments, the relationship between investment intensity and distress appears non-linear. Investment intensity plays a crucial role in increasing the probability of distress at low or zero debt levels, whereas the incremental negative effect appears to diminish at higher levels of debt. This is further affirmed by the marginal effects exhibited on Figure 5, showing that, up to a certain turning point, additional investments by both low-leverage and noleverage companies tend to accelerate the probability of the company becoming financially distressed, but if investments are made in relatively large volumes, they do not magnify the probability of distress that each additional unit of investment adds, but rather they decelerate growth in it.

The shape of the relationship between a company's investment intensity and its financial viability can be different depending on the extent of debt financing used for new investment. The more leveraged the investment financing is, the stronger the deceleration in the growth in the probability of distress beyond a certain turning point in investment intensity is. Decelerated distress probability is also reflected in marginal effects which are monotonously decreasing in investment intensity for leveraged firms. The firms using own financing to the contrary show marginal effects which peak at an annual investment level of $30 \%$ dropping thereafter. 
Table 3. IV estimates with a restricted definition for investments.

\begin{tabular}{|c|c|c|c|c|c|}
\hline Variable name & $\begin{array}{c}\text { IV Probit 2- } \\
\text { Step }\end{array}$ & IV Probit FIML & 2SLS & LIML & GMM \\
\hline \multicolumn{6}{|c|}{ FCS first wave: June-July 2009, N = 561} \\
\hline \multirow[t]{2}{*}{ ITSPPE } & $0.039^{*}$ & 0.026 & 0.010 & 0.012 & 0.011 \\
\hline & $(0.024)$ & $(0.016)$ & $(0.008)$ & $(0.010)$ & $(0.008)$ \\
\hline \multirow[t]{2}{*}{ LTC } & $0.033^{* * *}$ & $0.018^{* *}$ & $0.011^{* * *}$ & $0.011^{* * *}$ & $0.011^{* * *}$ \\
\hline & $(0.010)$ & $(0.008)$ & $(0.003)$ & $(0.004)$ & $(0.003)$ \\
\hline \multirow[t]{2}{*}{ Age } & -0.011 & -0.006 & -0.003 & -0.003 & -0.003 \\
\hline & $(0.017)$ & $(0.009)$ & $(0.005)$ & $(0.005)$ & $(0.005)$ \\
\hline \multirow[t]{2}{*}{ Size } & $-0.486^{* *}$ & $-0.272^{* *}$ & $-0.151^{* * *}$ & $-0.158^{* * *}$ & $-0.155^{* * *}$ \\
\hline & $(0.206)$ & $(0.122)$ & $(0.057)$ & $(0.061)$ & $(0.057)$ \\
\hline \multirow[t]{2}{*}{ Crisis, 2009} & 0.002 & 0.002 & 0.001 & 0.001 & 0.001 \\
\hline & $(0.005)$ & $(0.003)$ & $(0.001)$ & $(0.001)$ & $(0.001)$ \\
\hline \multirow[t]{2}{*}{ Intercept } & $-1.278^{* * *}$ & $-0.725^{* * *}$ & 0.083 & 0.064 & 0.076 \\
\hline & $(0.310)$ & $(0.155)$ & $(0.081)$ & $(0.087)$ & $(0.081)$ \\
\hline \multicolumn{2}{|l|}{ Log-Likelihood } & -5500 & & & \\
\hline chi-square & 19.404 & 112.704 & 26.636 & 24.168 & 27.662 \\
\hline $\mathrm{P}$ & 0.002 & 0.000 & 0.000 & 0.000 & 0.000 \\
\hline Over-identification test & 3.495 & 3.105 & 2.842 & 3.105 & \\
\hline Over-identificationp & 0.745 & 0.796 & 0.828 & 0.796 & \\
\hline \multicolumn{6}{|c|}{$\begin{array}{l}\text { FCS second wave: February-March 2010, } \\
\qquad N=277\end{array}$} \\
\hline \multirow[t]{2}{*}{ ITSPPE } & -0.002 & -0.004 & -0.000 & -0.001 & -0.000 \\
\hline & $(0.031)$ & $(0.082)$ & $(0.010)$ & $(0.030)$ & $(0.010)$ \\
\hline \multirow[t]{2}{*}{ LTC } & 0.018 & 0.022 & $0.006^{*}$ & 0.009 & $0.006^{*}$ \\
\hline & $(0.011)$ & $(0.014)$ & $(0.003)$ & $(0.008)$ & $(0.003)$ \\
\hline \multirow[t]{2}{*}{ Age } & 0.006 & 0.011 & 0.001 & 0.004 & -0.000 \\
\hline & $(0.019)$ & $(0.018)$ & $(0.006)$ & $(0.008)$ & $(0.006)$ \\
\hline \multirow[t]{2}{*}{ Size } & $-0.468^{*}$ & $-0.483^{*}$ & $-0.142^{*}$ & -0.188 & $-0.152^{* *}$ \\
\hline & $(0.241)$ & $(0.262)$ & $(0.074)$ & $(0.135)$ & $(0.073)$ \\
\hline \multirow[t]{2}{*}{ Crisis, 2009} & -0.002 & -0.000 & -0.001 & -0.000 & -0.000 \\
\hline & $(0.007)$ & $(0.008)$ & $(0.002)$ & $(0.003)$ & $(0.002)$ \\
\hline \multirow[t]{2}{*}{ Intercept } & $-0.987^{* *}$ & $-1.001^{* *}$ & 0.157 & 0.065 & 0.178 \\
\hline & $(0.397)$ & $(0.449)$ & $(0.124)$ & $(0.238)$ & $(0.122)$ \\
\hline \multicolumn{2}{|l|}{ Log-Likelihood } & -2600 & & & \\
\hline chi-square & 5.227 & 10.484 & 5.379 & 3.297 & 6.578 \\
\hline $\mathrm{P}$ & 0.389 & 0.063 & 0.371 & 0.654 & 0.254 \\
\hline Over-identification test & 7.591 & & 8.385 & 7.897 & 8.385 \\
\hline Over-identificationp & 0.27 & & 0.211 & 0.246 & 0.211 \\
\hline \multicolumn{6}{|c|}{ FCS third wave: May-June 2010, N = 268} \\
\hline \multirow[t]{2}{*}{ ITSPPE } & $0.141^{* *}$ & $0.073^{* * *}$ & $0.032^{*}$ & 0.039 & $0.032^{* *}$ \\
\hline & $(0.068)$ & $(0.019)$ & $(0.017)$ & $(0.025)$ & $(0.015)$ \\
\hline \multirow[t]{2}{*}{ LTC } & 0.003 & -0.003 & 0.001 & -0.000 & 0.003 \\
\hline & $(0.018)$ & $(0.012)$ & $(0.005)$ & $(0.007)$ & (0.005) \\
\hline \multirow[t]{2}{*}{ Age } & $-0.066^{* *}$ & -0.025 & $-0.015^{* *}$ & $-0.016^{* *}$ & $-0.017^{* * *}$ \\
\hline & $(0.034)$ & $(0.018)$ & $(0.006)$ & $(0.007)$ & $(0.006)$ \\
\hline \multirow[t]{2}{*}{ Size } & 0.366 & $0.199^{*}$ & 0.071 & 0.096 & 0.061 \\
\hline & $(0.382)$ & $(0.112)$ & (0.073) & (0.091) & $(0.074)$ \\
\hline \multirow[t]{2}{*}{ Crisis, 2009} & 0.006 & 0.002 & 0.001 & 0.001 & 0.001 \\
\hline & $(0.010)$ & $(0.005)$ & $(0.002)$ & $(0.002)$ & $(0.002)$ \\
\hline Intercept & $-1.017^{* *}$ & $-0.417^{* *}$ & $0.180^{*}$ & 0.159 & $0.192^{* *}$ \\
\hline
\end{tabular}


Table 3. IV estimates with a restricted definition for investments. (Continued)

\begin{tabular}{lccccc}
\hline Variable name & $\begin{array}{c}\text { IV Probit 2- } \\
\text { Step }\end{array}$ & IV Probit FIML & 2SLS & LIML & GMM \\
\hline & $(0.494)$ & $(0.17)$ & $(0.105)$ & $(0.124)$ & $(0.090)$ \\
Log-Likelihood & & -2500 & & & \\
chi-square & 9.876 & 52.903 & 14.382 & 12.587 & 26.868 \\
P & 0.079 & 0.000 & 0.013 & 0.028 & 0.000 \\
Over-identification test & 3.205 & & 2.472 & 1.802 & 2.472 \\
Over-identificationp & 0.783 & & 0.872 & 0.937 & 0.872
\end{tabular}

Source: Authors' calculations. Dependent variable is company distress from the FCS survey data. The cycle gap variable is from Eurostat, the other explanatory variables refer to 2007 data from the BEEPS.

Note: Hansen J-statistics used as over-identification test for 2SLS and GMM, Anderson-Rubin chi-square test used for LIML and Amemiya-Lee-Newey minimum chi-square statistics for IV-Probit. Heteroskedasticity robust standard errors in parenthesis, based on inverse of the outer product matrix (Hessian) or information matrix in sandwich form. ${ }^{* * *},{ }^{* *},{ }^{*}$ stand for $1 \%, 5 \%$ and $10 \%$ levels of statistical significance, respectively

\section{Conclusions}

In this article, we have disentangled the effects that pre-crisis investment intensity and the extent of debt financing had on company financial soundness in the aftermath of the global financial crisis of 2009/2010. Our study employs company-level data in a country comparative perspective of five Central and Eastern European countries-Bulgaria, Hungary, Latvia, Lithuania, and Romania.

Our contribution is twofold. First, we demonstrate a robust positive association between companies' financial distress and investment intensity, along with an intertwined effect with the extent of external financing used for the investments. Second, we show multiple non-linear relationships regarding distress probability and marginal effects at different levels of debt and investment. Like earlier literature, we find support for the positive impact of a company's size on its sustainability in our pooled sample; however, looking at different stages of the crisis, the company size increases resilience to crisis only at the onset or beginning of downturn in 2009, whereas its effect disappears or even reverses in later phases of the crisis in 2010. Although the age of the company was insignificant in explaining distress in pooled sample, its effect turned significant and negatively related to distress hazard only in later stages of crisis in the 2010 survey wave. The overall pattern shows that the first to be hit by the crisis are the small, highly geared companies followed by newly established firms which have made considerable investments pre-crisis.

Contrary to the conventional understanding, additional externally financed investments dampen the marginal hazard of financial distress. The higher the leverage in the investment financing, the stronger the decay in marginal effect upon the probability of distress. This implies that highly leveraged companies need to keep up high levels of investments in order to enhance productivity and generate revenues for maintaining and growing the business and serving the debts.

Our study stresses that the vulnerability of companies to the adverse economic environment in the aftermath of the Global financial crisis in 2009/2010 was driven by their pre-crisis investment and financing decisions. The larger the pre-crisis investments 
and debts were, the higher the company's probability of financial distress during the crisis turned out to be. Policy measures that encourage sustainable levels of investment and debt, and potentially provide support during a crisis to companies that have a sound investment and financing strategy, might alleviate some of the adverse effects of a crisis and promote more forward-looking financial decisions at the company level.

\section{Funding}

This project has received funding from the European Union's Horizon 2020 research and innovation program under the Marie Skłodowska-Curie grant agreement No 734712. The authors gratefully acknowledge support from grant PUT315 provided by the Estonian Research Council. The publication of this article is also supported by the Doctoral School of Economics and Innovation created under the auspices of European Social Fund. The financing institutions, however, had no involvement in the design and implementation of the research project.

\section{References}

Aghion, P., G.-M. Angeletos, A. Banerjee, and K. Manova. 2010. Volatility and growth: Credit constraints and the composition of investment. Journal of Monetary Economics 57:246-65.

Aghion, P., N. Berman, L. Eymard, P. Askenazy, and G. Cette. 2012. Credit constraints and the cyclicality of R\&D investment: Evidence from France. Journal of the European Economic Association 10(5), 1001-24. October.

Altman, E. I., M. Iwanicz-Drozdowska, E. K. Laitinen, and A. Suvas. 2014. Distressed firm and bankruptcy prediction in an international context: A review and empirical analysis of Altman's Z-score model (August 10, 2014). http://ssrn.com/ abstract=2536340. August 10.

Avarmaa, M., A. Hazak, and K. Männasoo. 2011. Capital structure formation in multinational and local companies in the Baltic States. Baltic Journal of Economics 11 (1):125-45.

Avarmaa, M., A. Hazak, and K. Männasoo. 2013. Does leverage affect labour productivity? A comparative study of local and multinational companies of the Baltic countries. Journal of Business Economics and Management 14 (2):252-75.

Aziz, A., and A. Dar. 2006. Predicting corporate bankruptcy: Where we stand? Corporate Governance 6 (1):18-33.

Aziz, A., D. C. Emanuel, and G. H. Lawson. 1988. Bankruptcy prediction - An investigation of cash flow based models. Journal of Management Studies 25 (5):419-35.

Aziz, A., and G. H. Lawson. 1989. Cash flow reporting and financial distress models: Testing of hypotheses. Financial Management 18:55-63. Spring.

Balcaen, S., and H. Ooghe. 2006. 35 years of studies on business failure: An overview of the classical statistical methodologies and their related problems. British Accounting Review 38 (1):63-93.

Barlevy, G. 2007. On the cyclicality of research and development. American Economic Review 97:1131-

64. Beaver, W. H. 1966. Financial ratios as predictors of failure. Journal of Accounting Research 4:71-111.

Bellovary, J., D. Giacomino, and M. Akers. 2007. A review of bankruptcy prediction studies: 1930 to present. Journal of Financial Education 33:1-42.

Bhattacharjee, A., C. Higson, S. Holly, and P. Kattuman. 2009. Macro economic instability and business exit: Determinants of failures and acquisitions of large UK firms. Economica 76:108-31.

Bickerdyke, I., R. Lattimore, and A. Madge. 2000. Business failure and change: An Australian perspective. Productivity Commission Staff Research Paper, Ausinfo, Canberra, ISBN 174037 029 5:1-192.

Campello, M., E. Giambona, J. R. Graham, and C. R. Harvey. 2011. Liquidity management and corporate investment during a financial crisis. Review of Financial Studies 24 (6):1944-79.

Črnigoj, M., and M. Verbič. 2014. Financial constraints and corporate investments during the current financial and economic crisis: The credit crunch and investment decisions of Slovenian firms. Economic Systems 38:502-17.

Dunne, P., and A. Hughes. 1994. Age, size, growth and survival: UK companies in the 1980s. The Journal of Industrial Economics 42 (2):115-40.

Fazzari, S., R. G. Hubbard, and B. C. Petersen. 1988. Financing constraints and corporate investment. Brookings Papers on Economic Activity 88:141-95.

Flagg, D., S. Kudrimoti, and S. Margetis. 2011. Do management decisions matter when firms are in distress? Review of Management Innovation \& Creativity 4 (9):1-19.

Gentry, J. A., P. Newbold, and D. T. Whitford. 1985a. Predicting bankruptcy: If cash flow's not the bottom line, what is?

Financial Analysts Journal 41 (5):47-56.

Gentry, J. A., P. Newbold, and D. T. Whitford. 1985b. Classifying bankrupt firms with funds flow components. 
Journal of Accounting Research 23 (1):146-60.

Gorodnichenko, Y., and M. Schnitzer. 2013. Financial constraints and innovation: Why poor countries don't catch up. Journal of the European Economic Association 11 (5):1115-52.

Hadlock, C. J., and J. R. Pierce. 2010. New evidence on measuring financial constraints: Moving beyond the KZ index. Review of Financial Studies 23:1909-40.

Harris, M., and A. Raviv. 1991. The theory of capital structure. The Journal of Finance 46 (1):297-355.

Hazak, A., and K. Männasoo. 2010. Indicators of corporate default: An EU based empirical study. Transformation in Business \& Economics 9 (1):62-76.

Hubbard, G. R. 1998. Capital-market imperfections and investment. Journal of Economic Literature 36 (1):193-225.

Kane, D. G., and F. M. Richardson. 2002. The relationship between changes in fixed plant investment and the likelihood of emergence from corporate financial distress. Review of Quantitative Finance and Accounting 18:25972.

Li, D. 2011. Financial constraints, R\&D investment, and stock returns. The Review of Financial Studies 24:2974-3007.

Männasoo, K., and P. Maripuu. 2015. Company performance, investment decision and cyclical sensitivity: A dynamic estimation on company micro-data. Eastern European Economics 53:1-14.

Maripuu, P., and K. Männasoo. 2014. Financial distress and cycle-sensitive corporate investments. Baltic Journal of Economics 14 (1-2):181193.

McKee, T. E., and T. Lensberg. 2002. Genetic programming and rough sets: A hybrid approach to bankruptcy classification.

European Journal of Operational Research 138:436-51.

Min, J. H., and Y.-C. Lee. 2005. Bankruptcy prediction using support vector machine (SVM) with optimal choice of kernel function parameters. Expert Systems with Applications 28:603-14.

Mohamed, E. B., B. Amel, and A. Bouri. 2013. Investment cash flow sensitivity and managerial optimism: A literature review via the classification scheme technique. The Review of Finance and Banking 05 (1):7-26.

Nivorozhkin, E. 2005. Financing choices of firms in EU accession countries. Emerging Markets Review 6 (2):138-69.

Ohlson, A. J. 1980. Financial ratios and the probabilistic prediction of bankruptcy. Journal of Accounting Research 18 (1):109-31. Popov, A. 2014. Credit constraints and investment in human capital: Training evidence from transition economies. Journal of Financial Intermediation 23 (1):76-100.

Richardson, F., G. Kane, and P. Lobingier. 1998. The impact of recession on the prediction of corporate failure. Journal of Business Finance and Accounting 25 (1\& 2):167-86.

Saeed, A., and O. Vincent. 2012. Bank concentration and firm investment: Empirical evidence from India. Emerging Markets Finance and Trade 48 (3):85-105.

Schoder, C. 2013. Credit vs. demand constraints: The determinants of US firmlevel investment over the business cycles from 1977 to 2011. The North American Journal of Economics and Finance 26:1-27.

Shleifer, A., and R. W. Vishny. 1997. A survey of corporate governance. The Journal of Finance 52 (2):737-83.

Syverson, C. 2011. What determines productivity? Journal of Economic Literature 49 (2):326-56.

Thornhill, S., and R. Amit. 2003. Learning about failure: Bankruptcy, firm age, and the resource-based view. Organization Science 14 (5):497-509.

Tian, X., and T. Y. Wang. 2014. Tolerance for failure and corporate innovation. Review of Financial Studies 27 (1):21155.

Tsai, B.-H. 2013. An early warning system of financial distress using multinomial logit models and a Bootstrapping approach. Emerging Markets Finance and Trade 49 (Supplement 2):43-69. 